\title{
ECONOMIC ANALYSIS OF SOME AGROTECHNICAL FACTORS IN MAIZE PRODUCTION. A HUNGARIAN CASE STUDY
}

\author{
Attila Bai ${ }^{1}$, Zoltán Gabnai ${ }^{1}$, Imre Kovách ${ }^{2}$, Ibolya Czibere ${ }^{3}$, János Nagy ${ }^{4}$, \\ Dénes Sulyok ${ }^{5}$, Donika Maloku ${ }^{6}$, Péter Balogh ${ }^{6}$
}

${ }^{1}$ University of Debrecen, Faculty of Economics and Business, Institute of Applied Economics ${ }^{2}$ University of Debrecen, Faculty of Humanities, Institute of Sociology, Hungarian Academy of Sciences, CSS ${ }^{3}$ University of Debrecen, Faculty of Humanities, Institute of Sociology

${ }^{4}$ University of Debrecen, Faculty of Agricultural and Food Sciences and Environmental Management, Institute of Land Use, Technology and Regional Development

${ }^{5}$ Maize and Industrial Plant Growing Cooperation (KITE) Plc., Nádudvar, Hungary

${ }^{6}$ University of Debrecen, Faculty of Economics and Business, Institute of Statistics and Research Methodology

bai.attila@econ.unideb.hu, gabnai.zoltan@econ.unideb.hu,

kovach.imre@arts.unideb.hu, czibere.ibolya@arts.unideb.hu,

nagyjanos@agr.unideb.hu, sulyokdenes@kite.hu,

donikamaloku03@gmail.com, balogh.peter@econ.unideb.hu

\begin{abstract}
This paper focuses on the economic and statistical evaluation of the production technology findings of the polyfactorial maize production experiments carried out between 2015-2017 at the Látókép Experiment Site of the University of Debrecen, Faculty of Agricultural and Food Sciences and Environmental Management. The examined agrotechnical factors included irrigation, previous crop, tillage, crop density, hybrid and $N$ nutrient supply, while the effect of different crop years was taken into consideration. In addition to descriptive statistical methods, we used multivariate regression analysis during the statistical evaluation. In the course of the evaluation, we examined three models that differed in terms of tillage methods and the consideration of crop year. In our best fit model, the factors were $71 \%$ responsible for the change in yield value. We carried out efficiency and comparative analyses in the course of the economic evaluation.

Averaged over the three examined years, it can be stated that nutrient supply and crop year had an outstanding effect on yield, while irrigation had a minimal effect. However, global warming may justify irrigation in the future, not only from a biological point of view, but also from an economic aspect.

Ideal tillage is also greatly affected by crop year, too. Altogether, of the examined tillage systems, subsoiling proved to be the best from an economic point of view.

Our investigations confirm that it is better to perform intensive farming under more favourable market conditions. The optimum of $N$ fertilisation is probably outside of the range we examined, if the extreme changes in maize and fertiliser prices are ignored.
\end{abstract}

Keywords: precision farming, year effect, fertilization, profit, efficiency

(JEL Classification: Q16, Q12, Q13, O32) 


\section{INTRODUCTION}

The success of maize production is fundamentally affected by the natural and economic conditions of production and the applied agrotechnology. At the same time, the economic evaluation of the obtained experiment findings and the drawing of generalisable conclusions can be seriously hindered, since the frequent change of weather and the fluctuation of inputoutput prices, the accelerated technological development, the reliable management of the cross-effects between individual expenditures and the prediction of future tendencies can only be performed on the basis of long-term experiments. Based on our hypothesis the optimum level of the fertilization is significantly affected by not only the input-, but also the output prices, depending on the other inputs' level and the weather's conditions. Our results might be useful for the adoptability of precision farming, which is a perspectivic segment of agriculture.

Our aim was to analyse the technological elements with the greatest impact on yields and profit (especially the applied tillage system and irrigation) with the help of different models. Based on the available data, we sought to determine the optimum active substance level of nitrogen fertiliser, which is also important for precision farming.

\section{Technical literature review}

Knowing the prevailing agro-ecological conditions (water supply, soil), the selection of the most appropriate hybrids and the harmonisation of agrotechnical elements with the economic and biological environment are essential for economical and sustainable maize production (Karancsi, 2015). In the recent decades, the physical, chemical and biological properties of Hungarian soils have deteriorated to a great extent, which also affects maize production. Only the use of hybrid-specific agrotechnical solutions adapted to the given production site can provide protection against the yield-reducing effects of climate change (Pepó, 2006). Many experiments have been carried out both in Hungary and in other countries with the aim to perform economically and environmentally sustainable maize production in the areas with different endowments and quality. These studies primarily examined the impact of different agrotechnical elements on each other and on the potentially obtainable yields.

The combination of production technology and agrotechnical elements fundamentally determines the costbenefit characteristics, i.e. the economicalness, profitability and environmental impact of the production activity. The applied tillage method, nutrient management and irrigation are widely examined agrotechnical elements.

Conservation tillage can be used for improving soil condition and soil life, for preserving soil moisture and for increasing humus content. The basic principles of this approach are reduced tillage, soil coverage and crop rotation. Examples include zero tillage, zone, strip or row tillage (Underwood et al., 2013). In the case of reduced tillage, similarly to conventional tillage, the entire surface is cultivated with or without ploughing. Combining or omitting certain operations can reduce the time and energy consumption per hectare by up to $50 \%$ (Husti, 2015). In zero tillage, light subsoiling is applied for deeper tillage, while discs and cultivators are used for shallow tillage (AKI, 2017). Sarauskis et al. (2011) discussed the positive effects of subsoiling, emphasising that this method of zero tillage can contribute to the proper air and water management of the soil and it prevents the leaching of nutrients caused by rainfall. Busari et al. (2015) discussed the importance of environmentally friendly tillage methods concerning sustainable crop production and climate change. The authors highlight the beneficial physical, chemical and biological effects of no-till solutions, reduced tillage, soil coverage, ridge tillage and contour tillage on the soil life of different soils. In many cases, compared to conventional tillage, environmental pollution impacts can be significantly reduced while achieving better yields. Accordingly, conservation tillage reduces greenhouse gas emissions through smaller interventions (machine work) and by increasing the organic carbon content of soils, and thus can be classified among "climate-smart" agricultural practices (Kuhn et al., 2016). In addition, these tillage methods contribute directly to the prevention of leaching and soil erosion (Bhatt et al., 2006).

Improving economic performance is a crucial factor regarding the spread of PF. Barnes et al. (2019), after interviewing 671 farmers in five different EU countries concluded that access to investment subsidies and the possibility of reducing annual costs were the most important aspects when farmers decided to buy and apply precision technology. According to the study carried out by Parihar et al. (2017) in India, the economic results and energy efficiency of the application of PF are greatly (6-60\%) influenced by the fertilization technology used in maize-wheat-mungobean crop rotation, depending on the crop year.

Based on the three-year comparative analysis of Ferencsik (2015), the fuel use of no-till technologies is about $35 \%$ (strip tillage) and 20\% (light subsoiling) lower than that of ploughing. The difference is mainly due to the difference in the energy demand of primary tillage, but the use of reduced tillage production technologies results in further savings. In terms of production costs, ploughing has the highest value (325 thousand HUF ha ${ }^{-1}$ ), followed by loosening (314 thousand HUF ha ${ }^{-1}$ ), while strip tillage has the lowest cost (306 thousand HUF ha' ${ }^{-1}$. According to Griffith et al. (1973) and Wittmuss et al. (1971), the yield potential of strip tillage is higher than, or (at least) the same as that of conventional tillage systems. However, this observation refers only to soils with good water management. Based on the results of Randall-Vetsch (2005), the yields achieved in conventional tillage in cold or rainy crop years may significantly exceed the yields achieved in reduced tillage systems.

Based on the long-term field experiment of the University of Debrecen at the Látókép Experiment Site, Sulyok (2005) and Nagy (2006a) demonstrated that autumn ploughing is the most preferred method of primary tillage for maize 
on calcareous chernozem soil in comparison with spring ploughing and disc tillage. At the same time, FerencsikRátonyi (2014) emphasised that strip tillage and loosening may be suitable alternatives to conventional ploughing on chernozem soil, especially in dry crop years.

Various research findings focused on the improvement of the N-efficiency of maize hybrids and the different yield responses obtained at different $\mathrm{N}$ levels. While the yield curve of the hybrids produced until the mid-1960s was flat in the case of applying 80-120 kg N, the optimal $\mathrm{N}$ dose of the hybrids produced in the 1970s was $160 \mathrm{~kg} \mathrm{ha}^{-1}$ (Győrffy, 1979 in Micskei, 2011).

According to Dóka and Pepó (2007), the amount of applied nitrogen has the greatest role in achieving the surpluses in maize yields, especially in the case of monoculture. Based on the analysis of Balla (2017), both the yield measured on the control plot and the plot on which $120 \mathrm{~kg} \mathrm{ha}^{-1}$ nitrogen was applied were significantly lower than the yield achieved as a result of the $240 \mathrm{~kg} \mathrm{ha}^{-1}$ nitrogen fertiliser treatment. The 10 $\mathrm{t} \mathrm{ha}^{-1}$ yield achieved as a result of applying $240 \mathrm{~kg} \mathrm{ha}^{-1} \mathrm{~N}$ was $1.59 \mathrm{t} \mathrm{ha}^{-1}$ higher than the average yield obtained in the case of applying $120 \mathrm{~kg} \mathrm{ha}^{-1} \mathrm{~N}$. As regards the control treatment, the harvested yield of $7.97 \mathrm{t} \mathrm{ha}^{-1}$ was $2.03 \mathrm{t} \mathrm{ha}^{-1}$ lower than most yields $\left(10 \mathrm{t} \mathrm{ha}^{-1}\right)$. However, the effect of nitrogen fertiliser is highly dependent on rainfall conditions. According to the long-term experiment findings of Széll and Kovácsné (1993), the yield increasing effect of nitrogen fertilisation, averaged over the 5 examined years, was $34 \%$ when $100 \mathrm{~kg} \mathrm{ha}^{-1} \mathrm{~N}$ was applied and $50 \%$ when $200 \mathrm{~kg} \mathrm{ha}^{-1} \mathrm{~N}$ was applied. However, in the case of rainy weather, the yield obtained in the case of the $300 \mathrm{~kg} \mathrm{ha}^{-1} \mathrm{~N}$ dose was almost as high as that of the $200 \mathrm{~kg} \mathrm{ha}^{-1} \mathrm{~N}$ dose. According to Árendás et al. (2000), the availability of nutrients is deteriorating in dry years, thus reducing the yield increasing effect. However, if moisture content is not a limiting factor, yield increased sharply until applying $100-120 \mathrm{~kg} \mathrm{ha}^{-1} \mathrm{~N}$, and the maximum yield was achieved as a result of applying $160-170 \mathrm{~kg} \mathrm{ha}^{-1} \mathrm{~N}^{-1}$ ha. At the same time, it can be concluded that the optimum amount of nitrogen fertiliser depends on the given crop year, as well as soil quality and the level of nitrogen supply (Nevens-Reheul, 2005; Berenguer et al., 2008; Ragán, 2017). Fertilisation is capable of partially compensating for other unfavourable agrotechnical endowments (Nagy, 2006b).

Long-term experiments have been carried out at the Látókép Experiment site, the location of our research, since 1983, the results of which have been published in several journals and a brief summary can be found in the paper of Nagy-Pepó (2015). The most important results of this polyfactorial maize experiments can be summarised as follows:

Optimum nitrogen fertiliser active substance in maize (1986-2012):

- monoculture: $180-240 \mathrm{~kg} \mathrm{ha}^{-1}$

- biculture: $120-180 \mathrm{~kg} \mathrm{ha}^{-1}$

Yield surplus due to irrigation (1986-2012):

$\begin{array}{ll}\text { - dry crop year: } & 3.4-5.4 \mathrm{t} \mathrm{ha}^{-1} \\ \text { - average crop year: } & 0.8-1.3 \mathrm{t} \mathrm{ha}^{-1}\end{array}$

Factors affecting maize yield the most (2004-2013):
- fertilisation: $\quad 39 \%$

- crop rotation: $28 \%$

- irrigation: $\quad 14 \%$

- crop year: $\quad 11 \%$

- population density: $7 \%$

\section{MATERIALS AND METHODS}

\section{Agroecological characteristics of the performed experiments}

Soil characterisation is based on the works of Sulyok et al (2006) and Nagy-Pepó (2015). The polyfactorial experiments carried out between 2015-2017 at the Látókép Experiment Site of the University of Debrecen, Faculty of Agricultural and Food Sciences and Environmental Management. The performed measurements consisted of 15 treatments of 6 production technology elements (4 replications each), and we were able to evaluate 972 yield results over the 3 examined years.

The experiment site is located on the Hajdúság loess ridge, $113-118 \mathrm{~m}$ asl. The greater part of the area is calcareous chernozem soil, while the lower part of the site is leached chernozem with meadow characteristics. The physical soil type is mid-heavy adobe. The proportion of gravity pores is significantly reduced in the $10-15 \mathrm{~cm}$ layer below the cultivated layer. As a result, water slowly leaves the cultivated layer. Groundwater is located 3-5 meters deep. The most important other soil properties are characterised with the following values:

Total porosity:

- in the cultivated layer: $\quad 44-48 \%$

- beneath the cultivated layer: $50-53 \%$.

Humus layer:

- thickness: $\quad 70-80 \mathrm{~cm}$,

- humus content: $\quad 2.5-3.0 \%$.

Soil

- acidity $(\mathrm{pH})$ : $\quad 6.2$ (mean value)

- total nitrogen content: $\quad 0.15 \%$ (average supply)

- AL-soluble $\mathrm{P}_{2} \mathrm{O}_{5}$ content: $133 \mathrm{ppm}$ (average supply level, heterogeneous distribution)

- AL-soluble $\mathrm{K}_{2} \mathrm{O}$ content: $\quad 240$ ppm (favourable supply level).

The climate in the area is basically continental, with increasingly frequent extreme temperatures and precipitation. The multiple-year average weather data can be characterised with the following numbers based on the data obtained by Nagy-Pepó (2015):

- mean temperature: $\quad 9.84 \mathrm{C}$ (increasing tendency)

- yearly precipitation: $565 \mathrm{~mm}$ (decreasing tendency)

- number of sunny hours: 2065

\section{Details of the experiment design}

Our analyses were performed on the database of the polyfactorial long-term tillage experiment established for three years (2015-2017) on the Látókép Experiment Site of 
the University of Debrecen, Faculty of Agricultural and Food Sciences and Environmental Management, Institute for Land Utilisation, Regional Development and Technology (Table 1).

Table 1: Agrotechnical characteristics of the experimental setup

\begin{tabular}{|c|c|c|c|}
\hline Irrigation & \multicolumn{3}{|c|}{ Irrigated, non-irrigated } \\
\hline Previous crop & \multicolumn{3}{|c|}{ E1 (maize), E2 (wheat) } \\
\hline Tillage & Autumn ploughing & Strip tillage & Subsoiling (50cm) \\
\hline Crop density & 60 thousand crops per ha, 80 thousand crops per ha \\
\hline Hybrid & $\begin{array}{c}\text { H1 (Armagnac, } \\
\text { FAO 490) }\end{array}$ & $\begin{array}{c}\text { H2 (Loupiac, } \\
\text { FAO 380) }\end{array}$ & $\begin{array}{c}\text { H3 (Sushi, FAO } \\
340)\end{array}$ \\
Fertilisation & $\begin{array}{c}\text { N1 = 0 kg N ha } \\
\text { Replications }\end{array}$ & $\begin{array}{c}\text { N2 }=80 \mathrm{~kg} \mathrm{~N} \\
\text { ha }{ }^{-1}\end{array}$ & $\begin{array}{c}\text { N3 }=160 \mathrm{~kg} \\
\mathrm{~N} \mathrm{ha}^{-1}\end{array}$ \\
\hline \multicolumn{3}{|c|}{4} \\
\hline
\end{tabular}

Source: Own construction based on the data collected by DE AGTC

The yearly amount precipitation in the examined years could be characterised with the following data:

- 2015: $518 \mathrm{~mm}$

- 2016: $818 \mathrm{~mm}$

- 2017: $641 \mathrm{~mm}$

From the aspect of our examinations, it is fortunate that the examined period included a dry crop year, a particularly rainy and an average crop year. In our analyses, we assumed that the required phosphorus and potassium supply in the soil is ensured to achieve the expected yields in the experiment.

Special factors in the economic evaluation of precision fertilisation

Comparative analyses were carried out between different input levels, technological variants and crop years during the economic evaluation. Data from non-irrigated, non-fertilised and ploughed plots were used as controls. There are two factors that make it difficult to determine optimal expenditure levels: - In addition to the proportions of prices, the obtained yields and the efficiency of resources used depend greatly on crop year and Liebig's law of the minimum, i.e., the given variety under examination, the prevailing soil conditions and the extent to which the amount of other expenditures is optimal. Due to the crop year effect, the optimum level is at different input levels each year, even in the same area, growing the same species and varieties. If an input is a bottleneck, the increase in other expenditures results in zero to slight yield increase.

- Determining the optimum technology and input level would presume the use of the lowest possible input ranges, with which the marginal efficiency can be calculated with sufficient accuracy. If the basic data necessary for accurate calculations are available, a longer time series is necessary to create reliable production functions that are to be verified under the conditions of the given production site in general (and not only for a few years).
This paper focuses on the correlations between the main production technological characteristics and the yield for a three-year period. Since the database of measurements contains extensive expenditure intervals, we did not calculate the marginal, but the average efficiency for the period between 2015-2017.

The basic economic data used in the performed calculations reflect the yearly mean data of the HCSO in 2017 (the final year of the experiments), except for maize prices, where the highest and lowest prices of the last 10 years have been taken into account. These are the following:

- $\quad$ N active substance price (2017):

- $\mathrm{N}$ active substance content of fertiliser: $32 \%$

- maize prices:

- minimum price: $27 \mathrm{HUF} \mathrm{kg}^{-1}$

- minimum price (2017):42.6 HUF $\mathrm{kg}^{-1}$

- maximum price: $56 \mathrm{HUF} \mathrm{kg}^{-1}$

- tillage costs:

- autumn ploughing and finishing: $27000 \mathrm{HUF} \mathrm{ha}^{-1}$

- subsoiling: 12000 HUF ha ${ }^{-1}$

- strip tillage: 13000 HUF ha-1

The variable data of the three model variants examined in $\mathrm{N}$-fertilisation is the price of maize, which is independent of yield (on average $10 \mathrm{t} \mathrm{ha}^{-1}$ ) in the model calculations; therefore, its change is equal to the effect of revenue per hectare.

\section{Statistical evaluation}

Due to the significant uncertainty factors, correlation analysis play an important role in our data analysis. In our evaluation, we developed and analysed multivariable linear regression models in addition to descriptive statistical indicators. Of the various descriptive statistical indicators, we calculated the mean, standard deviation, median, range, minimum and maximum values. In the regression models, we examined the effects on yield values for different maize sales prices. Of the different factors affecting the examined models, we were focusing on irrigation, previous crop, three different hybrids, different tillage methods, crop density and the different active substance amounts of the applied $\mathrm{N}$ fertiliser. For categorical variables, we used dummy coding to designate a given category as a reference category. Based on the regression parameters thus obtained, it was possible to quantify the effects of the other categories compared to the reference category.

\section{Model variables}

Three models were examined in our research. In our first two models, we analysed the data of the 3 examined years together and individually. In the third model, the examined years were incorporated as dummy variables. In the first two models, we used the average maize price of 2017 (42.6 HUF kg-1) in our calculations, while in the third model, we examined the effect of the change in maize prices using the minimum prices (27 HUF $\mathrm{kg}^{-1}$ ) 
and maximum prices (56 $\mathrm{HUF} \mathrm{kg}^{-1}$ ) in the last 10 years. In all three cases, we analysed the factors influencing yield value based on the available experimental data, which were the following in different models (factors different from the other models are in italics):

First model

$$
\mathrm{A}=\beta_{0}+\beta_{1} B+\beta_{2} C+\beta_{3} D_{1}+\beta_{4} D_{2}+\beta_{5} E+\beta_{6} F+\beta_{7} G
$$

- A: Maize revenue (HUF/ha)

- B: Irrigated and non-irrigated technology

- C: Previous crop (maize or wheat)

- $\mathrm{D}_{1} ; \mathrm{D}_{2}$ : Hybrids (H1 - basic category, H2, H3)

- E: Sowing seed costs in the case of germ numbers of 60 thousand and 80 thousand

- F: Fertiliser costs (in the case of 0/80/160 kg N active substance)

- G: Tillage system (general costs of autumn ploughing, subsoiling and strip tillage)

Second model

$\mathrm{A}=\beta_{0}+\beta_{1} B+\beta_{2} C+\beta_{3} D_{1}+\beta_{4} D_{2}+\beta_{5} E+\beta_{6} F+\beta_{7} G_{1}+\beta_{8} G_{2}$

- A: Maize revenue (HUF/ha)

- B: Irrigated and non-irrigated technology

- C: Previous crop (maize or wheat)

- $\mathrm{D}_{1} ; \mathrm{D}_{2}$ : Hybrids (H1 - basic category, H2, H3)

- E: Sowing seed costs in the case of germ numbers of 60 thousand and 80 thousand

- F: Fertiliser costs (in the case of 0/80/160 kg N active substance)

- $\mathrm{G}_{1} ; \mathrm{G}_{2}$ : A change in potential results (with dummy coding) to be obtained with the other two tillage systems (subsoiling, strip tillage) compared to autumn ploughing

Third model

$$
\begin{gathered}
\mathrm{A}=\beta_{0}+\beta_{1} B+\beta_{2} C+\beta_{3} D_{1}+\beta_{4} D_{2}+\beta_{5} E+\beta_{6} F+\beta_{7} G_{1}+ \\
\beta_{8} G_{2}+\beta_{9} Y_{2016}+\beta_{10} Y_{2017}
\end{gathered}
$$

- A: Maize revenue (HUF/ha)

- B: Irrigated and non-irrigated technology

- C: Previous crop (maize or wheat)

- $\mathrm{D}_{1} ; \mathrm{D}_{2}$ : Hybrids (H1 - basic category, H2, H3)

- E: Sowing seed costs in the case of germ numbers of 60 thousand and 80 thousand)

- F: Fertiliser costs (in the case of 0/80/160 kg N active substance)

- $\mathrm{G}_{1} ; \mathrm{G}_{2}$ : A change in yield value (with dummy coding) to be obtained with the other two tillage systems (subsoiling, strip tillage) compared to autumn ploughing

- Y2016; Y2017: Crop year effect (change in yield value in 2016 and 2017, compared to 2015 (with dummy coding))

\section{RESULTS}

\section{Descriptive statistical evaluation of the different models}

In this section, we present the statistical evaluation of fertilisation, irrigation, tillage and the crop year effect (ceteris

\begin{tabular}{|c|c|c|c|c|}
\hline & 2015 & 2016 & 2017 & $\begin{array}{l}\text { 3-year } \\
\text { average }\end{array}$ \\
\hline Yearly average yield $\left(\mathrm{t} \mathrm{ha}^{-1}\right)$ & 8.4 & 12.4 & 9.1 & 10 \\
\hline \multicolumn{5}{|c|}{ Effect of fertilisation } \\
\hline $\begin{array}{l}\text { Yield obtained with } 160 \mathrm{~kg} \\
\mathrm{ha}^{-1} \mathrm{~N} \text { active substance }\left(\mathrm{t} \mathrm{ha}^{-1}\right)\end{array}$ & 9.4 & 14.3 & 11.7 & 11.8 \\
\hline $\begin{array}{l}\text { Yield obtained with } 80 \mathrm{~kg} \mathrm{ha}^{-1} \\
\mathrm{~N} \text { active substance }\left(\mathrm{t} \mathrm{ha}^{-1}\right)\end{array}$ & 9.4 & 13.2 & 9.7 & 10.8 \\
\hline $\begin{array}{l}\text { Yield obtained with } 0 \mathrm{~kg} \mathrm{ha}^{-1} \\
\mathrm{~N} \text { active substance }\left(\mathrm{t} \mathrm{ha}^{-1}\right)\end{array}$ & 6.3 & 9.8 & 5.9 & 7.3 \\
\hline \multicolumn{5}{|c|}{ Effect of irrigation } \\
\hline Irrigated yield $\left(\mathrm{t} \mathrm{ha}^{-1}\right)$ & 8.6 & 12.1 & 9.1 & 9.9 \\
\hline Non-irrigated yield $\left(\mathrm{t} \mathrm{ha}^{-1}\right)$ & 8.1 & 12.8 & 9.1 & 10 \\
\hline \multicolumn{5}{|c|}{ Effect of tillage } \\
\hline Yield with ploughing $\left(\mathrm{t} \mathrm{ha}^{-1}\right)$ & 8.4 & 12.8 & 9.3 & 10.2 \\
\hline Yield with subsoiling $\left(\mathrm{t} \mathrm{ha}^{-1}\right)$ & 8.4 & 12.8 & 9.5 & 10.2 \\
\hline Yield with strip tillage $\left(\mathrm{t} \mathrm{ha}^{-1}\right)$ & 8.3 & 11.7 & 8.5 & 9.5 \\
\hline
\end{tabular}
paribus), using the indicators described in the methodology.

Table 2: The effect of the examined factors on the average yield

Source: own calculation

Table 2 clearly shows that the crop year of 2015 was unfavorable, 2016 was excellent, and 2017 was close to average on the basis of yield, parallel with rainfall conditions. In the crop year of 2015 (taking into account the additional costs of fertilisation and the additional yield value resulting from with it), it was reasonable to apply up to $80 \mathrm{~kg} \mathrm{ha}^{-1}$, while in the other two years, even up to $160 \mathrm{~kg} \mathrm{ha}^{-1}$ of $\mathrm{N}$ active substance was justified based on the approach of additionality, in the case of any maize price.

Averaged over the three examined years introduced in Table 2 , irrigation resulted in identical yields compared with the nonirrigated treatment, with a difference whose extent and direction depends on the rainfall amount and distribution of the examined crop years. Based on the obtained data, it can be concluded that, from the biological point of view, risk is greatly reduced by the installation of irrigation technology. However, from the economic point of view, irrigation has the opposite effect, due to the significant fixed costs (the depreciation costs of the equipment). Averaged over the three examined years, it can be stated that the minimum surplus yield $\left(0.1 \mathrm{t} \mathrm{ha}^{-1}\right.$ year $\left.^{-1}\right)$ did not make irrigation more profitable. However, based on the examination of several years, as well as the increase in the frequency of dry and warm crop years, irrigation farming may even be justified from the economic point of view in the future. A new national strategy to reduce the administrative costs of irrigation can contribute to this effort (Szilágyi, 2013; Government Decision 1426/2018).

In the case of the different tillage systems (Table 2), the 
old farmers' observation was partly confirmed, i.e., in rainy years, ploughing significantly increases yield, but alternative tillage methods could be more efficient in dry years. In this case, ploughing resulted in 0.8-1.1 $\mathrm{t} \mathrm{ha}^{-1}$ extra yield in comparison with strip tillage in better crop years, while the obtained yields were identical in 2015. In more favourable crop years, the increase in yield values outperformed the extra cost of ploughing, compared to strip tillage. Surprisingly, subsoiling resulted in the same yields in each crop year as that of ploughing, which justified subsoiling during the examined period, compared to both strip tillage (yield surplus) and ploughing (machine cost savings).

When examining individual expenditures, it can be clearly concluded that the fertiliser doses used in everyday practice can affect yield potential the most, as its value could reach at least $30-40 \%$ compared to the control treatment, thereby showing the importance of precision nutrient management, which aims for the most efficient fertiliser use. Irrigation and strip tillage systems require higher investment requirements compared to a control plot (non-irrigated, ploughing technology), which increases the risks in the economic sense, and the expected yield increase is also lower (below 10\% in both cases).

\section{Model evaluation}

\section{First model}

The first model was run in four different ways: the three years at once and each year separately. The value of the $F$ test was significant in each variant $(\mathrm{p}<0.001)$. The multivariate regression function fitted onto the three-year-long data series and the 2015 data had moderate fitting (R2: $39.7 \%$, and $47.5 \%$ ), while it was strong in the case of the other two crop years (2016: 63.2\%, 2017: 69\%). Accordingly, it can be concluded that, in the case of the best fitting model (2017 data), the factors were $69 \%$ responsible for yield value (Table 3 ).

Table 3: Statistical summary of the 1st model

\begin{tabular}{|c|c|c|c|c|c|c|c|}
\hline Model & R & $\begin{array}{c}\text { R } \\
\text { Square }\end{array}$ & \multicolumn{2}{|c|}{$\begin{array}{c}\text { Adjusted R } \\
\text { Square }\end{array}$} & F & df & Sig. \\
\hline $2015-2017$ & .630 & 0.397 & 0.395 & 182.104 & 7 & 1936 & .000 \\
\hline 2015 & .689 & 0.475 & 0.469 & 82.775 & 7 & 640 & .000 \\
\hline 2016 & .795 & 0.632 & 0.628 & 157.217 & 7 & 640 & .000 \\
\hline 2017 & .831 & 0.690 & 0.687 & 203.791 & 7 & 640 & .000 \\
\hline
\end{tabular}

Source: own calculation

When looking at the data of the three years together (Table 4), it can be concluded based on the standardised beta values that the cost of nutrient supply had the greatest impact on yield (0.56), followed by the previous crop (0.27) and both factors had significant effect. The effect of the other parameters was below 0.05 . Of them, the effect of hybrid 3 was significant in comparison with hybrid 1 , while the cost of tillage was also significant. Of the expenditures expressed in monetary value, only the efficiency of applying fertiliser was above 1 (5.4 HUF HUF $^{-1}$ ), while one-unit increase of the other examined expenditures (crop density, tillage) did not result in any income (beta values below 1).
Table 4: Regression coefficients of the 1st model

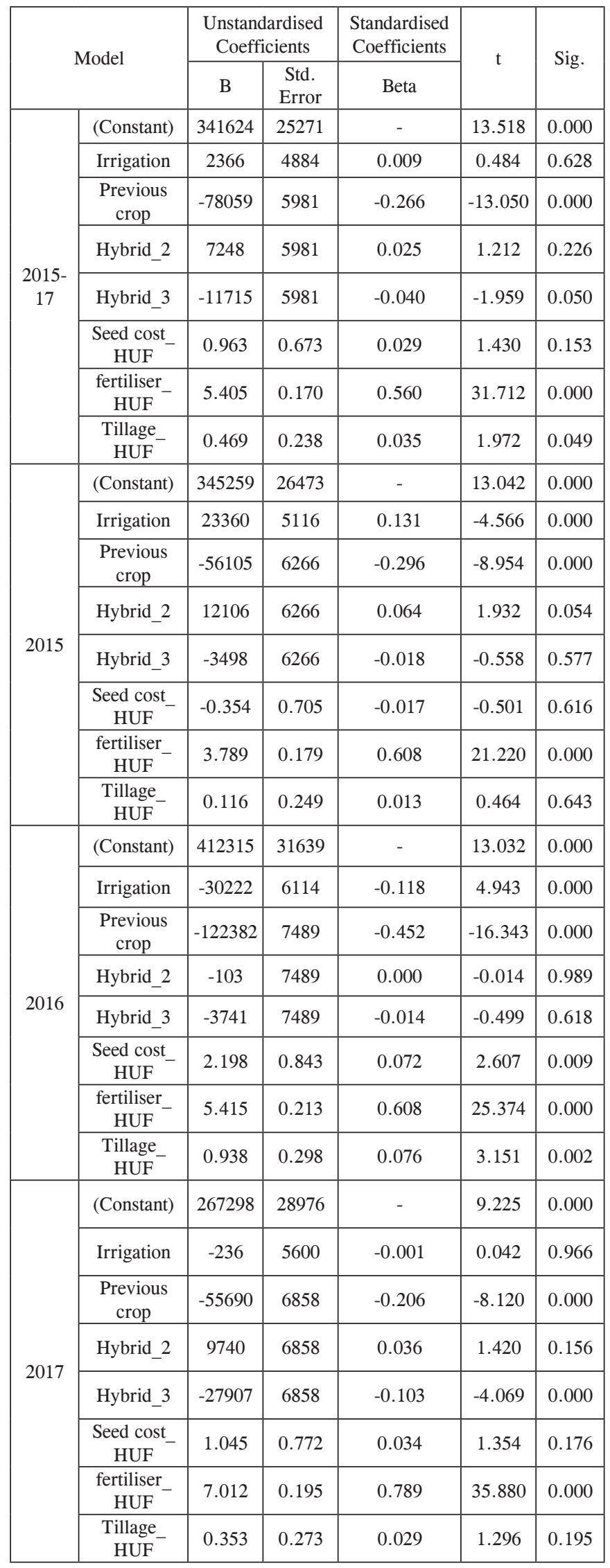

Source: own calculation 
The crop year effect can be summarised in comparison with the 3-year joint model as follows:

2015: Due to the less precipitation in 2015, irrigation had a notable and significant positive effect on yield value (value of the standardised coefficient: 0.13 , beta value: $23360 \mathrm{HUF} \mathrm{ha}^{-1}$ ), while the effect of fertilisation and previous crop remained similar. Although the efficiency of fertilisation is still effective, its value decreased significantly $\left(3.8\right.$ HUF HUF $\left.^{-1}\right)$.

2016: Due to the rainy crop year, the effect of irrigation was similar to that of the previous year, but it had a negative value (standardised coefficient: -0.12 , beta value: -30222 HUF ha-1). The peculiarity of this year is that, besides the outstanding cost efficiency of fertilisation, the increase of sowing seed costs is also effective (2.2 HUF HUF $\left.^{-1}\right)$.

2017: In this year, irrigation had no significant impact on yield value. Both the potency (standardised coefficient: 0.79 ) and efficiency of fertilisation (7 HUF $\mathrm{HUF}^{-1}$ ) are outstanding. The effect of previous crop remains significant $(0.21,-55690$ HUF ha ${ }^{-1}$ ) and has a significant effect on yield value. In this year, the impact of hybrid 3 compared to that of hybrid 1 also played an important role in gaining profits $\left(-27906 \mathrm{HUF}^{-1} \mathrm{ha}^{-1}\right)$.

\section{Second model}

The second model was also run in four different ways: the three years at once and each year separately. The value of the $F$ test was significant in each variant $(p<0.001)$. The multivariate regression function fitted onto the three-year-long data series and the 2015 data had moderate fitting (R2: $40.6 \%$, and $47.6 \%$ ), while it was strong in the case of the other two crop years (2016: $65.4 \%, 2017: 71 \%)$. Accordingly, it can be concluded that, in the case of the best fitting model (2017 data), the factors were $71 \%$ responsible for yield value (Table 5).

Table 5: Statistical summary of the 2nd model

\begin{tabular}{|c|c|c|c|c|c|c|c|c|}
\hline Model & $\mathrm{R}$ & $\begin{array}{c}\mathrm{R} \\
\text { Square }\end{array}$ & $\begin{array}{c}\text { Adjusted } \\
\text { R Square }\end{array}$ & $\begin{array}{c}\text { Std. } \\
\text { Error } \\
\text { of the } \\
\text { Estimate }\end{array}$ & \multicolumn{2}{|c|}{$\mathrm{F}$} & $\mathrm{df}$ & Sig. \\
\hline $2015-17$ & .637 & 0.406 & 0.404 & 106887 & 165.324 & 8 & 1935 & $<0.001$ \\
\hline 2015 & .690 & 0.476 & 0.469 & 65115 & 72.554 & 8 & 639 & $<0.001$ \\
\hline 2016 & .809 & 0.654 & 0.650 & 75496 & 151.308 & 8 & 639 & $<0.001$ \\
\hline 2017 & .842 & 0.710 & 0.706 & 69046 & 195.370 & 8 & 639 & $<0.001$ \\
\hline
\end{tabular}

Source: own calculation

When looking at the data of the three years together (Table 6), it can be concluded based on the standardised beta values that the cost of nutrient supply had the greatest impact on yield (0.56), followed by the previous crop (0.27) and strip tillage (0.09).

The effect of hybrid 3 was only $4 \%$ in comparison with hybrid 1 . Of the expenditures expressed in monetary value, only the efficiency of applying fertiliser was above 1 (5.4 HUF HUF $^{-1}$ ), while one unit increase of the other examined expenditures (previous crop, seed cost, strip tillage) did not result in any income (beta values below 1).
Table 6: Regression coefficients of the 2nd model

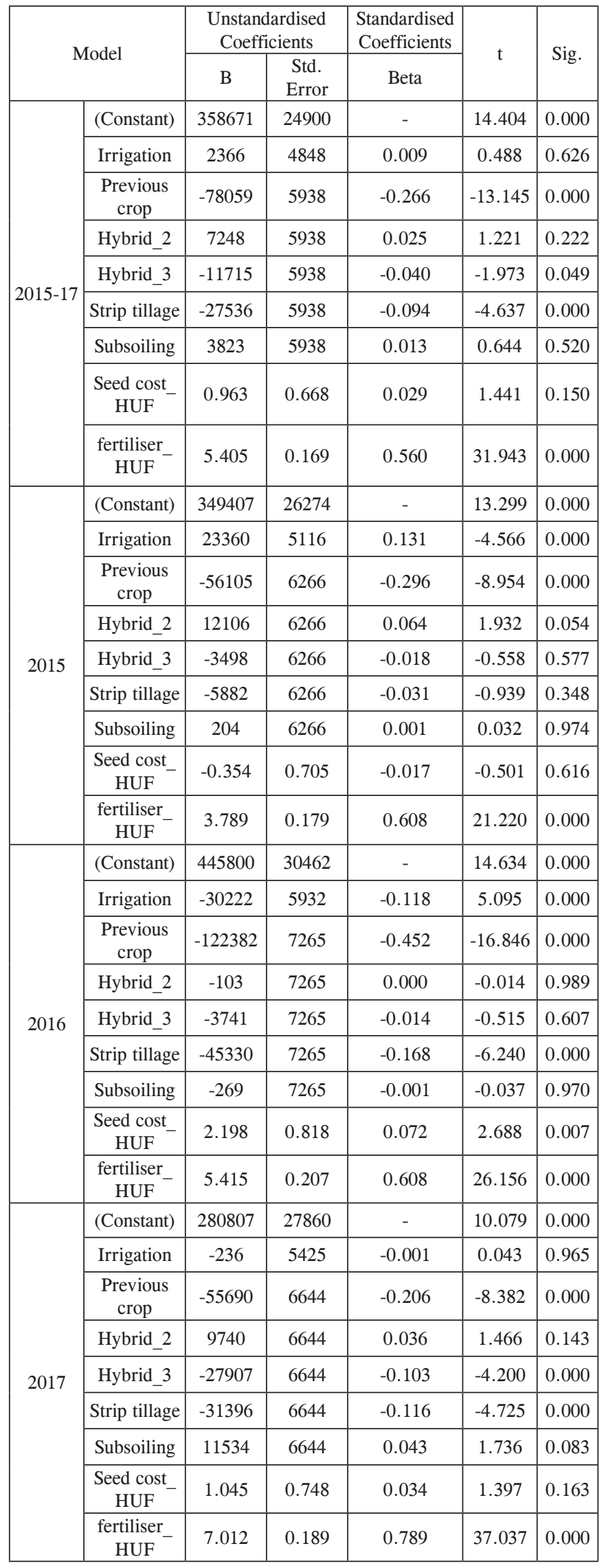

Source: own calculation 
The crop year effect compared to the 3-year joint model was perfectly identical to that observed in the case of the 1 st model.

\section{Third model}

The third version of the model was run with three different maize prices (27 $\mathrm{HUF} \mathrm{kg}^{-1}$, $42.6 \mathrm{HUF} \mathrm{kg}^{-1}$ and $56 \mathrm{HUF} \mathrm{kg}^{-1}$ ), and the different years were built into the model as dummy variables. As only the maize prices differed in these models, the value of the F-test was significant ( $p<0.001)$ for each variant and only the error of function fitting (Std. Error Of the Estimate) was different. The fitted multivariate regression functions properly characterised the examined baseline data (r2: 70\%); and the error of fitting of the model was the most significant (Std. Error of the Estimate: 99609) in the case of the highest maize price (56 HUF kg-1) (Table 7).
Table 7: Statistical summary of the 3rd model

\begin{tabular}{|c|c|c|c|c|c|c|c|c|}
\hline Model & $\mathrm{R}$ & $\begin{array}{c}\mathrm{R} \\
\text { Square }\end{array}$ & $\begin{array}{l}\text { Adjust- } \\
\text { ed R } \\
\text { Square }\end{array}$ & $\begin{array}{l}\text { Std. Error } \\
\text { of the } \\
\text { Estimate }\end{array}$ & $\mathrm{F}$ & & df & Sig. \\
\hline $42.60 \mathrm{Ft}$ & .838 & 0.702 & 0.700 & 75775 & 454.88 & 10 & 1933 & $<0.001$ \\
\hline $27 \mathrm{Ft}$ & .838 & 0.702 & 0.700 & 48026 & 454.88 & 10 & 1933 & $<0.001$ \\
\hline $56 \mathrm{Ft}$ & .838 & 0.702 & 0.700 & 99610 & 454.88 & 10 & 1933 & $<0.001$ \\
\hline
\end{tabular}

Source: own calculation

Taking into account the three different maize prices for each variant, it can be established on the basis of standardised beta values that the examined variables had different effects on yield

Table 8: Regression coefficients of the 3rd model

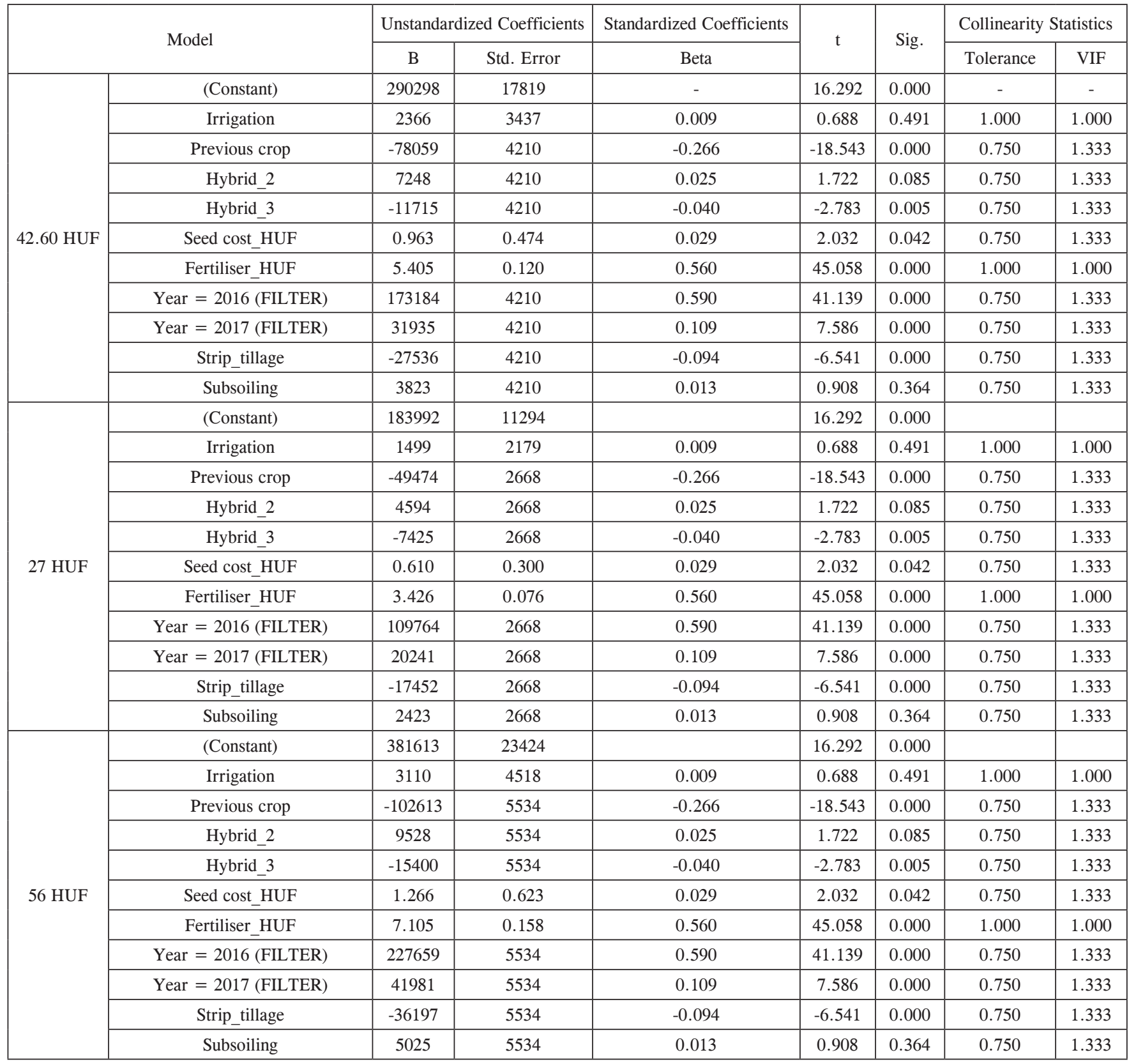


in the following order. The biggest impact was seen in 2016 (0.59), compared to 2015. The cost of nutrient supply had the second greatest effect $(0.56)$, followed by the effect of previous crop (0.27) and 2017 (0.11), compared to 2015. Strip tillage had the next significant effect (0.09) - compared to autumn ploughing. Seed cost (0.03) had a significant impact, too. The effect of the other examined parameters was not significant.

As shown in Table 8, of the expenditures indicated in monetary value, in addition to the cost of fertiliser application (3.4; 5.4 and 7.1 HUF $\mathrm{HUF}^{-1}$ ) and the price of maize (56 HUF), the effect of seed cost (1.3 HUF $\left.\mathrm{HUF}^{-1}\right)$ was above 1 , and one-unit increase of the other expenditures (previous crop, tillage) did not result in extra income (beta values below 1). At the same time, the impact of crop year resulted in an increase in income compared to the 2015 base year in the case of all maize prices. Compared to 2015, the year 2017 had a smaller impact on revenue growth $(20,32$ and 42 thousand HUF), while the impact of 2016 (compared to 2015) was the most significant (110, 173 and 228 thousand HUF).

Determining the optimum nitrogen active substance dose

Based on the examined regression models, we also analysed the impact of the change in maize prices over the past 10 years on the cost-effectiveness of fertilisation. As a matter of course, higher maize prices justify the use of higher fertiliser doses or more expensive fertilisers. On the basis of the examined data, one unit change in fertiliser prices result in the following revenue change in a similar direction in the case of the 2017 prices and the maximum and minimum maize prices during the last 10 years (Table 9).

Table 9: The effect of fertiliser prices on maize revenue

\begin{tabular}{|c|c|}
\hline Maize price (thousand HUF $\mathrm{t}^{-1}$ ) & Regression coefficient of fertiliser \\
\hline 27 & 3.426 \\
\hline 42.6 & 5.405 \\
\hline 56 & 7.105 \\
\hline
\end{tabular}

Source: own calculation

Based on Table 9, we concluded that the average efficiency of $\mathrm{N}$ fertiliser use in the $0-160 \mathrm{~kg} \mathrm{ha}^{-1}$ range is far beyond the efficiency of both bank deposite and loan rate, even at low maize prices, which can be justified with higher risks from the economic aspect. The available data characterises only two active substance intervals (0-80 and 80-160 kg $\mathrm{ha}^{-1}$ ), and the yield value surpluses they result in. As a matter of course, these values are only average figures, and the marginal efficiency of initial expenditures is much higher. At the same time, in the case of maximum doses, their application may no longer be recommended from the economic aspect. As a consequence, we made calculations to determine the optimum active substance level, which is suitable for achieving the economic outcomes above the bank investment level in the case of different model variants.

The effect of average maize prices on the revenue per hectare is shown in Table 10, averaged over all examined experimental parameters and all three years, using the most commonly used descriptive statistical indicators.
Table 10: Descriptive statistics of revenue per hectare in the case of different model variants

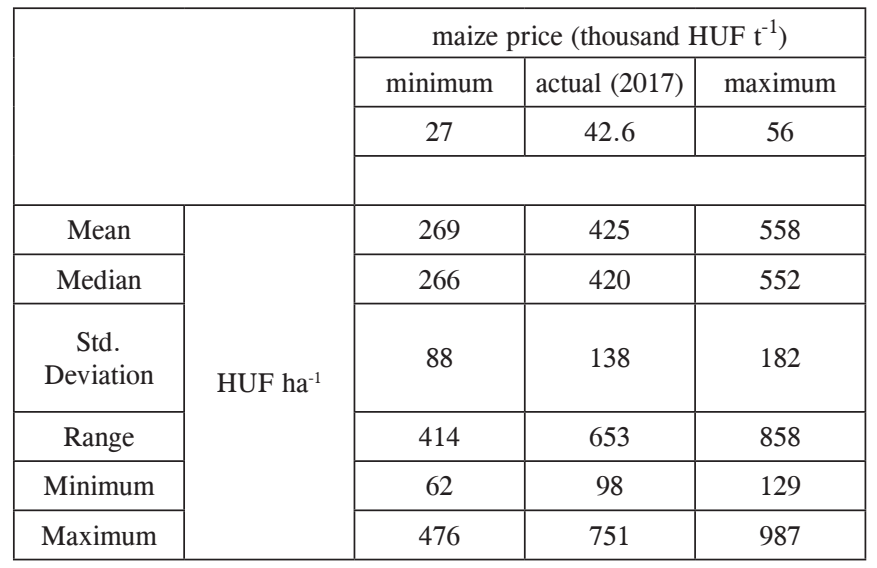

Source: own calculation

The average potential revenue based on Table 10 ranges between 269-558 thousand HUF ha ${ }^{-1}$, i.e., the worst and best market prices, while the standard deviation is between 88-182 thousand HUF ha ${ }^{-1}$, which means a $32 \%$ coefficient of variation, suggesting that the reason for the observed significant heterogeneity is due to different experimental settings.

An important part of our economic analyses is the calculation of the fertiliser dose that is economically rewarding. The optimum level of production function is significantly affected by the selling price of maize, the considered opportunity cost, the regression coefficient for fertilisation shown in Table 9 and the active ingredient content of the $\mathrm{N}$ fertiliser, among other factors. Considering the effect of all these factors, the active substance content per hectare is shown in Table 11.

Table 11: $\mathrm{N}$ fertiliser active substance content to be recommended in the case of various maize prices

\begin{tabular}{|c|c|c|c|c|}
\hline \multicolumn{2}{|c|}{} & \multicolumn{3}{|c|}{ maize price Ft/kg } \\
\cline { 3 - 5 } & minimum & 2017 & maximum \\
\cline { 3 - 5 } & 27 & 42.6 & 56 \\
\cline { 3 - 5 } yield value & $\begin{array}{c}\text { thousand HUF } \\
\text { ha }^{-1}\end{array}$ & 269 & 425 & 558 \\
\hline $\begin{array}{c}\text { average fertil- } \\
\text { iser cost * }\end{array}$ & $\begin{array}{c}\text { thousand HUF } \\
\text { ha }^{-1}\end{array}$ & 50 & 79 & 103 \\
\hline $\begin{array}{c}\text { fertiliser } \\
\text { doses* }\end{array}$ & $\mathrm{kg} \mathrm{ha}^{-1}$ & 227 & 359 & 472 \\
\hline $\begin{array}{c}\text { active sub- } \\
\text { stance content* }\end{array}$ & $\mathrm{kg} \mathrm{ha}^{-1}$ & 73 & 115 & 151 \\
\hline
\end{tabular}

*based on the obtained regression coefficients

\section{Source: own calculation}

Maize price, as expected, has a very pronounced effect on the optimal dose of the fertiliser active substance and varies between $73-151 \mathrm{~kg} \mathrm{ha}^{-1}$ in each model. These values are true only in the case of the $\mathrm{N}$ active substance price of 219 HUF 
$\mathrm{kg}^{-1}$, which is considered to be the current price. The change in active substance prices result in an identical, but opposite change of the optimum dose.

We would like to emphasise that the three fertilisation levels available to us $\left(0,80,160 \mathrm{~kg} \mathrm{~N}^{-1}\right)$ provide a very limited opportunity for accurate decision-making. Figure 1 shows the average sales revenue for each fertilisation level, as well as the optimum active substance content obtained above. Figure 1 shows, in line with the principle of diminishing returns, that sales revenue increases until the expenditure level of $80 \mathrm{~kg} \mathrm{ha}^{-1}$. After this point, revenue increased to a significantly lower extent, i.e., it is more appropriate to carry out more intensive farming activities under more favourable market conditions.

Figure 1: Yield value to be obtained with nitrogen active substance doses used in the performed experiments.

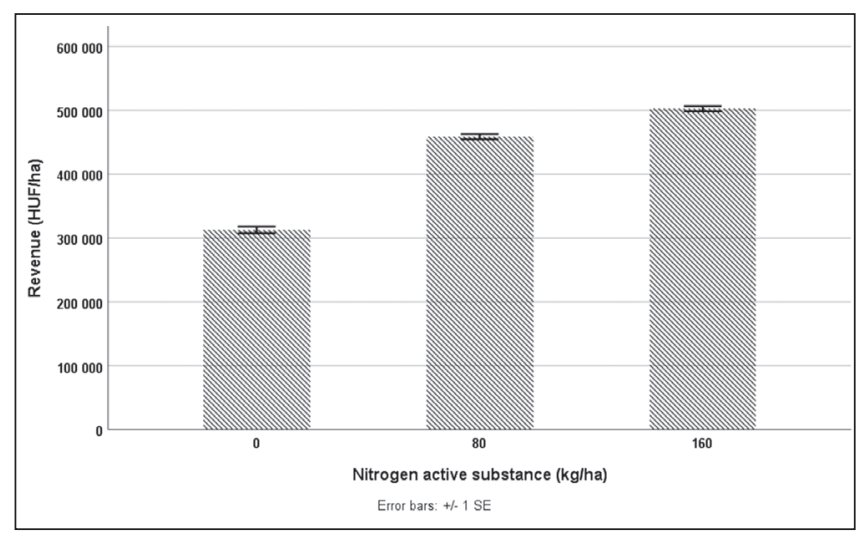

Source: own calculation

\section{DISCUSSION AND CONCLUSIONS}

The obtained experimental findings confirm that yield shows a very close correlation with the yearly precipitation conditions in the case of all examined expenditures. Favourable crop years and irrigation are the main reasons for higher level of outputs, according to production functions.

Contrary to the earlier experiments at Látókép (NagyPepó, 2015), irrigation resulted in practically identical yields with non-irrigated treatments (averaged over the three examined years). The difference between them depended on the extent and nature of the rainfall of each examined year. However, these differences were much smaller than in previous experiments.

It is important to emphasise that, although biological considerations and climate change may justify the installation of irrigation technology, there is a definite risk from an economic point of view, due to the significant increase in fixed costs.

In the rainy crop years, the economic outcome of ploughing far exceeded that of strip tillage, which corresponds to the findings of Randall-Vetsch (2005). Based on our calculations, however, subsoiling was more competitive than strip tillage (yield surplus) and ploughing (machine cost savings) during the three examined years.
By dividing the maize prices by the regression coefficients, it is possible to calculate the fertiliser cost per hectare, which can be considered typical (average) for the given experiments, although its efficiency varies. Since the latter value ranges between $343-711 \%$ (the additional fertilizer cost of 1 HUF results in an increase of 3.43-7.11 HUF in yield value, depending on the maize price), it significantly exceeds the considerable values of opportunity cost. Using the $\mathrm{N}$ active substance price, the obtained fertiliser cost per hectare was converted into fertiliser amount and, based on the $\mathrm{N}$ active substance content, into active substance amount, which can be used to achieve the average fertilisation efficiency of the performed experiments.

Of the individual expenditures, the rational increase of fertiliser doses is capable of affecting successful maize production both biologically (30-40\% increase in yield and a weight of 0.56 in affecting yield) and economically (5.4 HUF HUF $^{-1}$ average efficiency). These findings greatly support the importance of precision nutrient management. The second most important factor in yield was the previous crop effect (0.27). Our results attribute greater importance to fertilisation, while that of the previous crop is the same as the previous examinations at Látókép (Nagy-Pepó, 2015).

Of the random factors, the crop year effect significantly affected yields (0.11-0.59), resulting in a yield surplus of 32 HUF $\mathrm{ha}^{-1}$ in an average year and $173 \mathrm{HUF} \mathrm{ha}^{-1}$ in a rainy year, compared to a dry crop year.

According to our calculations, the average efficiency of the use of $\mathrm{N}$ fertiliser in the $0-160 \mathrm{~kg} \mathrm{ha}^{-1}$ active substance range far exceeds the efficiency of banking investments, even at low maize prices. On the basis of the three-year average and the principle of additional efficiency, it is also advisable to apply $160 \mathrm{~kg} \mathrm{ha}^{-1} \mathrm{~N}$, provided that the marginal efficiency of doses close to $160 \mathrm{~kg} \mathrm{ha}^{-1}$ is obviously significantly lower than the additional efficiency of the examined range; therefore, the accurate determination of the economical dose of active ingredient calls for applying significantly lower dose than the $80 \mathrm{~kg} \mathrm{ha}^{-1}$ fertilisation range (with differences being up to $10 \mathrm{~kg} \mathrm{ha}^{-1}$ ). This calculation is in line with all previous experimental results (Nagy-Pepó, 2015; Balla, 2017; Dóka-Pepó, 2007; Győrffy, 1979), which confirm that the optimum of $\mathrm{N}$ fertilisation is above $120 \mathrm{~kg}$ ha-1. It should be noted that, in the European Union, there is a legal limit on $\mathrm{N}$ application from the environmental point of view (Nitrate Directive (1991) and Nitrate Regulation (2008), $170 \mathrm{~kg} \mathrm{ha}^{-1}$ year $\left.^{-1}\right)$.

At the same time, the change in active substance prices may be significant and result in an identical, but opposite change of the optimum dose.

\section{ACKNOWLEDGEMENTS}

This research was supported by EFOP-3.6.2-16-201700001 project (Research of complex rural economic and sustainable development, elaboration of its service networks in the Carpathian basin).

The research was financed by the Higher Education 
Institutional Excellence Programme (NKFIH-1150-6/2019) of the Ministry of Innovation and Technology in Hungary, within the framework of the 4th thematic programme of the University of Debrecen.

The authors would like to acknowledge the collaboration of Prof. Dr. László Fodor and Dr. Ágnes Bujdos in this research work, who contributed in the legal background of the precision farming.

\section{REFERENCES}

AKI (2017): A precíziós szántóföldi növénytermesztés összehasonlító vizsgálata. Szerk.: Kemény, G., Lámfalusi, I., Molnár, A. Agrárgazdasági Kutató Intézet. DOI: http://dx.doi. org/10.7896/ak1703

Árendás, T., Berzsenyi, Z., Szundy, T., Marton, L. Cs., Bónis, P. (2000): Kukorica - Termesztőknek. Gyakorlati Agrofórum. 11(3):44-47.

Balla, Z. (2017): Az agrotechnikai tényezôk hatása a kukorica hibridek termésére és keményítőhozamára. Doktori (PhD) Értekezés. Debreceni Egyetem, Kerpely Kálmán Doktori Iskola. Debrecen. pp. 150.

Barnes, A. P., Soto, I., Eory, V., Beck, B., Balafoutis, A., Sánchez, B., Vangeyte, J., Fountas, S., van der Wal, T., Gómez-Barbero, M. (2019): Exploring the adoption of precision agricultural technologies: A cross regional study of EU farmers. Land Use Policy. 80:163-174.

Berenguer, P., Santiveri, F., Boixadera, J., Lloveras, J. (2008): Fertilisation of irrigated maize with pig slurry combined with mineral nitrogen. Eur. J. Agron. 28(4):635-645.

Bhatt, R., \& Khera, K. L. (2006). Effect of tillage and mode of straw mulch application on soil erosion in the submontaneous tract of Punjab, India. Soil and Tillage Research, 88(1-2), $107-$ 115 .

Busari, M. A., Kukal, S. S., Kaur, A., Bhatt, R., \& Dulazi, A. A. (2015). Conservation tillage impacts on soil, crop and the environment. International Soil and Water Conservation Research, 3(2), 119-129.

Dóka, L. F., Pepó, P. (2007): Role of watersupply in monoculture maize (Zea mays L.) production. Cereal Res. Commun. 35 (2): 353-356.

Ferencsik, S., Rátonyi, T. (2014): Evaluation of striptillage and conventional tillage in maize production. Acta Agraria Debreceniensis, (59), 37-40.

Ferencsik, S. (2015): A kukorica hagyományos és csökkentett menetszámú talajmúvelési rendszereinek komplex elemzése. Doktori (PhD) Értekezés. Kerpely Kálmán Doktori Iskola. Debreceni Egyetem. Debrecen, 2015. pp. 120.

Griffith, D. R., Mannering, J. V., Galloway, H. M., Parsons, S. D., Richey, C. B. (1973): Effect of eight tillage-planting systems on soil temperature, percent stand, plant growth, and yield of corn on five Indiana soils. Agronomical Journal. 65: 321-326.

Győrffy, B. (1979): Fajta-, növényszám- és mủtrágyahatás a kukorica-termesztésben. Agrártudományi Közlemények. 38: 309-331

Husti, I. (2015): A sávmúvelés néhány múszaki-ökonómiai kérdése hazánkban. Mezőgazdasági Technika. 56 (8): 26-29.
Karancsi, L. G. (2015): Eltérő genotípusú kukorica hibridek tápanyag reakciójának és minőségének vizsgálata csernozjom talajon. Doktori (PhD) Értekezés. Hankóczy Jenó Növénytermesztési, Kertészeti és Élelmiszertudományok Doktori Iskola. Debreceni Egyetem. Debrecen, 2015.

Kuhn, N. J., Hu, Y., Bloemertz, L., He, J., Li, H., \& Greenwood, P. (2016). Conservation tillage and sustainable intensification of agriculture: regional vs. global benefit analysis. Agriculture, Ecosystems \& Environment, 216, 155-165.

Micskei, Gy. (2011): Szerves- és mútrágya hatásának összehasonlító vizsgálata a kukorica produkciójára tartamkísérletben. Doktori (PhD) Értekezés. Szent István Egyetem. Martonvásár, 2011.

Nagy J. (2006a): A debreceni kukorica tartamkísérletek eredményei In: Nagy J., Dobos A. (szerk.) Környezetkímélő növénytermesztés-minőségi termelés. DE Agrártudományi Centrum. Debrecen, 2006. pp. 7-48.

Nagy, J. (2006b): Maize Production. Food - Bioenergy - Forage. Szakkönyv. Akadémiai Kiadó, Budapest. ISBN 978963058636 8. pp. 391

Nitrát-irányelv: Az Európa Tanács irányelve (1991. december 12.) a vizek mezőgazdasági eredetű nitrátszennyezéssel szembeni védelmérôl; III. melléklet 2 . pontja

Nitrát-rendelet: 59/2008. (IV. 29.) FVM rendelet a vizek mezőgazdasági eredetű nitrátszennyezéssel szembeni védelméhez szükséges cselekvési program részletes szabályairól, valamint az adatszolgáltatás és nyilvántartás rendjéről; 4. § (1) bekezdés.

Nagy, J., Pepó, P. (2015): Tartamkísérletek. Debrecen - Látókép. Debreceni Egyetem, Agrártudományi Központ. ISBN 978-6155451-02-7. pp. 51.

Nevens, F., Reheul, D. (2005): Agronomical and environmental evaluation of a long-term experiment with cattle slurry and supplemental inorganic $\mathrm{N}$ applications in silage maize. Eur. J. Agron. 22:349-361.

Parihar, C. M., Jat, S. L., Singh, A. K., Majumdar, K., Jat, M. L., Saharawat, Y. S., Pradhan, S., Kuri, B. R. (2017): Bioenergy, water-use efficiency and economics of maize-wheatmungbean system under precision-conservation agriculture in semi-arid agro-ecosystem. Energy. 119:245-256.

Pepó, P. (2006): Fejlesztési alternatívák a magyar kukoricatermesztésben. Gyakorlati agrofórum extra. 13. 7-11. p.

Ragán P. (2017): A műtrágyázás és az öntözés interakciójának vizsgálata a kukoricatermesztésben. Doktori $(\mathrm{PhD})$ Értekezés. Kerpely Kálmán Doktori Iskola. Debreceni Egyetem. Debrecen, 2017. pp. 151.

Randall, G. W., Vetsch, J. A. (2005): Optimum tillage systems for corn and soybean production and water quality protection in South Central Minnesota - Minnesota River Basin. University of Minnesota, Extension Service publication.

Sarauskis, E., Romaneckas, K., Vaiciukevicius, E., Jasinskas, A., Sakalauskas, A., Buragiene, S., Katkevicius, E., Karayel, D. (2011, May). Effect of environmentally friendly tillage machinery on soil properties. In Proceedings of 10 th International scientific conference „Engineering for Rural Development (pp. 70-75).

Sulyok, D. (2005): Az alternatív talajmúvelési rendszerek eredményességének vizsgálata. Doktori (PhD) Értekezés. Debrecen, 2005. pp. 133. 
Széll, E., Kovácsné Komlós M. (1993): Hozzászólások a „Tápanyagok nélkül?" címú riporthoz. Agrofórum. 4(9):23.

Szilágyi, J. E. (2013): Vízjog. Aktuális kihívások a vizek szabályozásában. Miskolci Egyetem, Miskolc, 2013, pp. 262.

Underwood, E., Baldock, D., Aiking, H., Buckwell, A., Dooley, E., Frelih-Larsen, A., Naumann, S., O'Connor, C., Poláková, J., Tucker, G. (2013): A fenntartható élelmiszeripar és mezőgazdaság alternatívái az EU-ban. Összefoglaló jelentés a STOA „Technológiai alternatívák 10 milliárd ember élelmezésére” projektjéről. Európai Környezetpolitikai Intézet. London/Brüsszel.

Wittmuss, H. D., Lane, D. E., Somerhalder, B. R. (1971): Strip till-planting of row crops through surface residue. Trans. ASAE. 14:60-68. 